\title{
Acute Pancreatitis Associated with Pegylated Interferon and Ribavirin Treatment of Chronic Hepatitis C, Genotype 1 b with High Viral Load
}

\author{
Kenji Ando ${ }^{a}$ Soo Ryang Kim ${ }^{a}$ Susumu Imoto ${ }^{a}$ \\ Taisuke Nakajima $^{a}$ Keiji Mita $^{a}$ Katsumi Fukuda ${ }^{a}$ \\ Miyuki Taniguchia ${ }^{a}$ Noriko Sasase $^{a} \quad$ Akira Muramatsu $^{b}$ \\ Toshiyuki Matsuokac Masatoshi Kudod \\ Yoshitake Hayashi ${ }^{\mathrm{e}}$ \\ aDepartment of Gastroenterology, Kobe Asahi Hospital, Kobe, ${ }^{b}$ Division of Liver \\ Diseases, Meimai Central Hospital, Akashi, 'Department of Radiology, Osaka City \\ University Medical School, Osaka, 'Department of Gastroenterology and \\ Hepatology, Kinki University School of Medicine, Osakasayama, and 'Division of \\ Molecular Medicine and Medical Genetics, International Center for Medical \\ Research and Treatment, Kobe University Graduate School of Medicine, Kobe, \\ Japan
}

\section{Key Words}

Acute pancreatitis - Pegylated interferon - Ribavirin - Chronic hepatitis $C$, high serum hepatitis C viral RNA - Genotype 1b · Tumor necrosis factor-a - Interleukin-6 .

Drug-induced pancreatitis

\begin{abstract}
Acute pancreatitis, an uncommon side effect of pegylated interferon a (PEG-IFN a) and ribavirin (RBV) combination therapy, has rarely been reported in the English language literature. Here, acute pancreatitis associated with PEG-IFN plus RBV treatment is described in three patients with chronic hepatitis $C$, genotype $1 \mathrm{~b}$ with high serum hepatitis $C$ virus RNA levels. The patients had been started on weekly subcutaneous injections of PEG-IFN a $(60,80$, and $90 \mu \mathrm{g})$ plus a daily oral dose of RBV $(600 \mathrm{mg})$. The therapy was discontinued, however, because of the onset of acute pancreatitis (after 15 weeks, 48 weeks, and 3 weeks respectively). The drug-induced pancreatitis was diagnosed on the basis of elevated levels of amylase and lipase and the absence of other identifiable causes. High tumor necrosis factor-a was found in one patient and high interleukin- 6 in the other two. The immune system stimulated by PEG-IFN and RBV combination therapy might have caused the acute pancreatitis. Further study is needed
\end{abstract}


to clarify the mechanism of the onset of drug-induced pancreatitis by PEG-IFN and RBV combination therapy.

\section{Introduction}

Acute pancreatitis is an uncommon side effect of interferon $\alpha$ (IFN $\alpha$ ) and ribavirin (RBV) combination therapy, and only few such cases have been reported in the English language literature [1]. It has been described in three cases of hepatitis $C$ virus (HCV)-infected patients treated with pegylated interferon (PEG-IFN) plus RBV [2-4]. The pathogenesis of acute pancreatitis related to a stimulated immune system, however, has not been described. We present three cases of acute pancreatitis which may have been caused by the immune system stimulated by tumor necrosis factor alpha (TNF- $\alpha$ ) and interleukin-6 (IL-6) associated with PEG-IFN plus RBV treatment of chronic hepatitis C (CHC), genotype $1 \mathrm{~b}$ with high serum HCV RNA levels.

\section{Case 1}

A 67-year-old woman with CHC was admitted to Kobe Asahi Hospital in September 2007 for the treatment of abdominal pain. In June 2007, the patient with $44 \mathrm{~kg}$ body weight had been started on a weekly subcutaneous injection of $60 \mu$ g of PEG-IFN $a-2 b$ plus a daily oral dose of $600 \mathrm{mg}$ RBV. Reverse transcription-polymerase chain reaction (RT-PCR) revealed 2,300 kIU/ml of HCV RNA and the hepatitis B surface antigen (HBsAg) and hepatitis B virus DNA were negative. The HCV core antigen by a new immunoradiometric assay was $5,550 \mathrm{fmol} / \mathrm{l}$, and the genotype was $1 \mathrm{~b}$. Laboratory tests revealed the following: total protein (TP) $6.2 \mathrm{~g} / \mathrm{dl}$ (normal 6.7-8.3), albumin (ALB) $3.8 \mathrm{~g} / \mathrm{dl}$ (normal 3.8-5.3), aspartate aminotransferase (AST) $40 \mathrm{IU} / \mathrm{l}$ (normal 0-38), alanine aminotransferase (ALT) $29 \mathrm{IU} / \mathrm{l}$ (normal 0-19), platelets (PL) $13.9 \times 10^{4} / \mu \mathrm{l}$ (normal 14-34); liver biopsy revealed stage 1 fibrosis. The patient tolerated the therapy well until week 14 , when she presented with severe epigastric pain radiating to her back, nausea, and vomiting. Laboratory tests at that time revealed the following: amylase (AMY) 178 IU/l (normal 38-136), lipase (LIPA) 521 IU/l (normal 23-300), AST 29 IU/l, ALT $10 \mathrm{IU} / \mathrm{l}$, alkaline phosphatase (ALP) $226 \mathrm{IU} / \mathrm{l}$ (normal 110-354), total billirubin (T-BIL) $0.5 \mathrm{mg} / \mathrm{dl}$ (normal 0.2-1.2), white blood cell (WBC) count $50 \times 10^{2} / \mu \mathrm{l}$ (normal 40-90), calcium (Ca) $9.4 \mathrm{mg} / \mathrm{dl}$ (normal 8.7-10.1), total cholesterol (T-CHO) $140 \mathrm{mg} / \mathrm{dl}$ (normal 150-219), triglycerides (TG) $153 \mathrm{mg} / \mathrm{dl}$ (normal 50-149), IgG4 $20.1 \mathrm{mg} / \mathrm{dl}$ (normal 4.8-105). TNF- $\alpha$ and IL-6 were $8.8 \mathrm{pg} / \mathrm{ml}$ (normal $<5.0$ ) and $3.4 \mathrm{pg} / \mathrm{ml}$ (normal $<4.0$ ), respectively. The patient had no history of pancreatitis, denied alcohol use, and was not taking any medications. Imaging studies such as ultrasound (US), computed tomography (CT) and magnetic resonance imaging (MRI) revealed no swelling of the pancreas or dilation of the pancreatic duct. The gallbladder appeared normal and no gallstones were noted. PEG-IFN $a-2 b$ and RBV were discontinued at 15 weeks after the start of therapy, and the patient was treated with ulinastatin 150,000 units/day for 4 weeks and camostat mesilate $600 \mathrm{mg}$ /day orally for two weeks under the diagnosis of acute pancreatitis. The pancreatitis resolved and the patient was discharged in December 2007.

\section{Case 2}

A 60-year-old man was admitted to Kobe Asahi Hospital in October 2007 for the treatment of appetite loss and general fatigue. In November 2006 the patient with $58 \mathrm{~kg}$ body weight had been started on a weekly subcutaneous injection of $80 \mu \mathrm{g}$ of PEG-IFN a-2b plus a daily oral dose of $600 \mathrm{mg}$ RBV for the treatment of CHC. The RT-PCR revealed $5,100 \mathrm{kIU} / \mathrm{ml}$ of HCV RNA, and the genotype was $1 \mathrm{~b}$; HBsAg was negative. Laboratory tests revealed the following: TP $8.8 \mathrm{~g} / \mathrm{dl}$, ALB $3.5 \mathrm{~g} / \mathrm{dl}$, AST 53 IU/l, ALT 36 IU/l, PL $9.9 \times 10^{4} / \mu \mathrm{l}$; liver biopsy was not done.

The patient tolerated the therapy well and completed the 48-week course of PEG-IFN plus RBV in September 2007. Soon thereafter, the patient presented with appetite loss and general fatigue. Laboratory tests at admission revealed the following: AMY 316 IU/l, LIPA 1,373 IU/l, AST 42 IU/l, ALT $10 \mathrm{IU} / \mathrm{l}$, ALP $312 \mathrm{IU} / \mathrm{l}$, T-BIL $0.5 \mathrm{mg} / \mathrm{dl}$, WBC count $34 \times 10^{2} / \mu \mathrm{l}, \mathrm{Ca} 7.7 \mathrm{mg} / \mathrm{dl}$, T-CHO $135 \mathrm{mg} / \mathrm{dl}$, TG 
$107 \mathrm{mg} / \mathrm{dl}$, IgG4 $5.5 \mathrm{mg} / \mathrm{dl}$. TNF- $\alpha$ and IL- 6 were $\leq 5$ and $12.8 \mathrm{pg} / \mathrm{ml}$, respectively. The patient had no history of pancreatitis, denied alcohol use, and was not taking any medications. US, CT and MRI revealed no swelling of the pancreas or dilation of the pancreatic duct. The gallbladder appeared normal and no gallstones were noted. The patient was treated with ulinastatin 150,000 units/day for 3 weeks under the diagnosis of acute pancreatitis. The pancreatitis resolved and the patient was discharged in November 2007.

\section{Case 3}

A 75-year-old woman, admitted to Kobe Asahi Hospital in April 2008 for the treatment of CHC, had $44 \mathrm{~kg}$ body weight and was started on a weekly subcutaneous injection of $90 \mu \mathrm{g}$ of PEG-IFN $\alpha$-2a plus a daily oral dose of $600 \mathrm{mg}$ RBV. TaqMan real-time PCR revealed $6.9 \log \mathrm{kIU} / \mathrm{ml}$ of HCV RNA and the genotype was $1 \mathrm{~b}$; HBsAg and hepatitis B virus DNA were negative. Laboratory tests revealed the following: TP $7.1 \mathrm{~g} / \mathrm{dl}$, ALB $3.7 \mathrm{~g} / \mathrm{dl}$, AST $78 \mathrm{IU} / \mathrm{l}$, ALT $112 \mathrm{IU} / \mathrm{l}$, PL $7.7 \times 10^{4} / \mu \mathrm{l}$; the liver biopsy revealed stage 3 fibrosis. The patient tolerated the therapy well until week 3 , after which she complained of severe epigastric pain radiating to her back, nausea, and vomiting. Laboratory tests at that time revealed the following: AMY 155 IU/l, LIPA 1,153 IU/l, AST 43 IU/l, ALT 62 IU/l, ALP 213 IU/l, T-BIL $0.3 \mathrm{mg} / \mathrm{dl}$, WBC count $98 \times 10^{2} / \mu \mathrm{l}$, Ca $8.9 \mathrm{mg} / \mathrm{dl}$, T-CHO $120 \mathrm{mg} / \mathrm{dl}$, TG $161 \mathrm{mg} / \mathrm{dl}, \mathrm{IgG} 424.2 \mathrm{mg} / \mathrm{dl}$. TNF- $\alpha$ and IL- 6 were 1.8 and $7.9 \mathrm{pg} / \mathrm{ml}$, respectively. The patient had no history of pancreatitis, denied alcohol use, and was not taking any medications. Imaging studies such as US, CT and MRI revealed no swelling of the pancreas or dilation of the pancreatic duct. The gallbladder appeared normal and no gallstones were noted. PEG-IFN $\alpha-2 a$ and RBV were discontinued at 3 weeks after the start of therapy, and the patient was treated with ulinastatin 150,000 units/day for 4 weeks and camostat mesilate $600 \mathrm{mg} /$ day for 4 weeks under the diagnosis of acute pancreatitis. The pancreatitis resolved and the patient was discharged in June 2008 (table 1).

\section{Discussion}

Drug-induced pancreatitis is an uncommon side effect of IFN $\alpha$, although several such cases have been published. Acute pancreatitis is described in a 9-year-old girl treated for 14 months with IFN $\alpha, 3$ million units daily, for chronic myelogenous leukemia [5]. Two other incidences of acute pancreatitis are described in adults treated with high doses (up to 10 million units daily) of IFN a for chronic myelogenous leukemia: one of the two patients developed recurrent pancreatitis after being rechallenged with a daily dose of 10 million units of IFN $\alpha$ [6].

In the English language literature, only one case of acute pancreatitis has been reported in a 38-year-old man with HCV treated with only IFN $\alpha$. The patient developed acute pancreatitis $2 \mathrm{~h}$ after receiving the first 5 million units injection of IFN $\alpha-2 b$. Although his symptoms resolved within 2 days, the patient developed recurrent pancreatitis 5 weeks after being rechallenged with 3 million units of IFN $a-2 b$ [7].

Onset of pancreatitis has not been reported among 1,010 patients treated with IFN $\alpha-2 b$ plus RBV therapy in a large international multicenter registration trial [8]. Although only few cases of acute pancreatitis have been reported in patients treated with IFN $\alpha-2 b$ and RBV combination therapy [1], the acute pancreatitis has been attributed to $\mathrm{RBV}$, with the antiviral treatment being resumed with IFN alone. Nonetheless, such patients developed acute pancreatitis within hours of being rechallenged with IFN $a-2 b$. Acute pancreatitis has been reported in 3 cases of $\mathrm{HCV}$-infected patients treated with PEG-IFN plus RBV therapy [2-4]; however, its pathogenesis has not been described.

In our cases, the drug-induced acute pancreatitis was diagnosed on the basis of the presence of symptoms such as epigastric pain, appetite loss, elevated amylase and lipase levels, and the absence of other identifiable causes of pancreatitis. The patients showed no evidence of gallstones, alcohol consumption, or other potential causes of pancreatitis such 
as autoimmune pancreatitis with no elevation of IgG4. These findings meet the criteria for probable drug-induced pancreatitis. The onset of pancreatitis during PEG-IFN $a$ plus RBV therapy and the resolution of the symptoms after discontinuing the treatment confirmed our diagnosis. Moreover, the consequent absence of recurrent pancreatitis also suggested that the medications were the most likely cause of acute pancreatitis.

PEG-IFN and RBV combination therapy is a potential cause of drug-induced pancreatitis in patients with CHC, and IFN $\alpha$ can cause pancreatitis through several potential mechanisms. Treatment with IFN $\alpha$ can result in severe hypertriglyceridemia, a well-described cause of acute pancreatitis. In our cases, however, severe hypertriglyceridemia was not observed. Alternatively, PEG-IFN a may cause acute pancreatitis by stimulating the immune system, leading to autoimmune destruction of the pancreas. High TNF- $\alpha$ and IL- 6 have been described as inducing and mediating acute pancreatitis, as have immunomodulatory cytokines $[9,10]$. Indeed, high TNF- $\alpha$ was observed in case 1 and high IL-6 in cases 2 and 3. IFN $\alpha$ is known to precipitate or exacerbate other autoimmune disorders such as thyroid disease and diabetes. Based on the published literature, IFN $\alpha$ is more likely than RBV to cause acute pancreatitis, although RBV is known to exert immunomodulatory effects; also, RBV alone or synergistically with IFN a may stimulate the immune system to cause pancreatitis through an autoimmune mechanism. In our cases, however, high TNF- $\alpha$ (case 1) and high IL-6 (cases 2 and 3) may be markers of immune system stimulation by PEG-IFN and RBV or by acute pancreatitis itself.

In conclusion, PEG-IFN $\alpha$ and RBV combination therapy is a potential cause of drug-induced pancreatitis in patients with CHC. In such individuals, pancreatitis is often severe enough to warrant hospitalization, although symptoms promptly resolve after discontinuation of antiviral therapy. Patients should be closely monitored during treatment and the medications should be discontinued when signs or symptoms of acute pancreatitis appear. Further studies are warranted to determine which of these two medications is associated with drug-induced pancreatitis, to investigate the mechanisms of pancreatic injury, and to evaluate the incidence of acute pancreatitis in $\mathrm{HCV}$-infected patients treated with PEG-IFN and RBV.

Table 1. Clinical profile of the three patients with acute pancreatitis

\begin{tabular}{|c|c|c|c|c|c|c|c|c|c|c|}
\hline Case & $\begin{array}{l}\text { Age } \\
\text { (years) }\end{array}$ & Gender & IFN & IFN dose & RBV dose & $\begin{array}{l}\text { Duration of } \\
\text { treatment* }\end{array}$ & $\begin{array}{l}\text { AMY } \\
\text { (IU/l) }\end{array}$ & $\begin{array}{l}\text { LIPA } \\
\text { (IU/l) }\end{array}$ & $\begin{array}{l}\text { TNF- } \alpha \\
(\mathrm{pg} / \mathrm{ml})\end{array}$ & $\begin{array}{l}\text { IL-6 } \\
(\mathrm{pg} / \mathrm{ml})\end{array}$ \\
\hline Case 1 & 67 & female & PEG-IFN $a-2 b$ & $60 \mu \mathrm{g} /$ week & $600 \mathrm{mg} q \mathrm{~d}$ & 15 weeks & 178 & 521 & 8.8 & 3.4 \\
\hline Case 2 & 60 & male & PEG-IFN $a-2 b$ & $80 \mu \mathrm{g} /$ week & $600 \mathrm{mg}$ qd & 48 weeks & 316 & 1,373 & $\leq 5$ & 12.8 \\
\hline Case 3 & 75 & female & PEG-IFN a-2a & $90 \mu \mathrm{g} /$ week & $600 \mathrm{mg}$ qd & 3 weeks & 155 & 1,153 & 1.8 & 7.9 \\
\hline
\end{tabular}

* Duration of PEG-IFN $a$ and RBV treatment before diagnosis of acute pancreatitis. Normal ranges: AMY 38-136 IU/l, LIPA 23-300 IU/l, TNF- $\alpha<5.0$ pg/ml, IL-6 $<4.0$ pg/ml. qd = Daily. 


\section{References}

1 Chaudhari S, Park J, Anand BS, Pimstone NR, Dieterich DT, Batash S, Bini EJ: Acute pancreatitis associated with interferon and ribavirin therapy in patients with chronic hepatitis C. Dig Dis Sci 2004;49:1000-1006.

-2 Cecchi E, Forte P, Cini E, Banchelli G, Ferlito C, Mugelli A: Pancreatitis induced by pegylated interferon alfa- $2 \mathrm{~b}$ in a patient affected by chronic hepatitis $\mathrm{C}$. Emerg Med Australas 2004;16:473-475.

-3 Ozdogan O, Tahan V, Cincin A, Imeryuz N, Tozun N: Acute pancreatitis associated with the use of peginterferon. Pancreas 2007;34:485-487.

4 Tahan V, Tahan G, Dane F, Uraz S, Yardim M: Acute pancreatitis attributed to the use of pegylated interferon in a patient with chronic hepatitis C. J Gastrointest Liver Dis 2007;16:224-225.

5 Sotomatsu M, Shimoda M, Ogawa C, Morikawa A: Acute pancreatitis associated with interferon-alpha therapy for chronic myelogenous leukemia. Am J Hematol 1995;48:211-212.

-6 Tannir NM, Talpaz M, Ghazal H, Proothi S, Kantarjian HM: Acute pancreatitis associated with interferon alpha therapy for chronic myelogenous leukemia. Leuk Lymphoma 2000;39:647-650.

7 Eland IA, Rasch MC, Sturkenboom MJ, Bekkering FC, Brouwer JT, Delwaide J, Belaiche J, Houbiers G, Stricker BH: Acute pancreatitis attributed to the use of interferon alfa-2b. Gastroenterology 2000;119:230-233.

-8 Poynard T, Marcellin P, Lee SS, Niederau C, Minuk GS, Ideo G, Bain V, Heathcote J, Zeuzem S, Trepo C, Albrecht J: Randomized trial of interferon alpha $2 \mathrm{~b}$ plus ribavirin for 48 weeks or for 24 weeks versus interferon alpha $2 \mathrm{~b}$ plus placebo for 48 weeks for treatment of chronic infection with hepatitis $\mathrm{C}$ virus. International Hepatitis Interventional Therapy Group (IHIT). Lancet 1998;352:1426-1432.

-9 Heath DI, Cruickshank A, Gudgeon M, Jehanli A, Shenkin A, Imrie CW: Role of interleukin- 6 in mediating the acute phase protein response and potential as an early means of severity assessment in acute pancreatitis. Gut 1993;34:41-45.

10 Grewal HP, Kotb M, el Din AM, Ohman M, Salem A, Gaber L, Gaber AO: Induction of tumor necrosis factor in severe acute pancreatitis and its subsequent reduction after hepatic passage. Surgery 1994;115:213-221. 